\title{
Seasonal and Diel Activity Variations in the Shrimp Palaemon adspersus from a Brackish, Non- Tidal Area
}

\author{
L. Hagerman and J. Østrup \\ Marine Biological Laboratory, DK-3000 Helsinger, Denmark
}

\begin{abstract}
Seasonal and diel activity rhythms of the natantian shrimp Palaemon adspersus Rathke from a non-tidal area were investigated in the laboratory by means of photocells. $P$. adspersus is nocturnal, with maximum activity levels in summer and early autumn, and minimum levels in winter and early spring. When the nights are short the activity consists of 1 brief, intense period; it extends to $2-3$ periods when the nights are prolonged. The change from 2 to 1 activity periods is very sharp at the end of April. The total length of the active period was $10 \mathrm{~h}$ per $24 \mathrm{~h}$ throughout the year. Length of active period and subdivision into smaller periods is considered to be regulated by an endogenous mechanism. Seasonal variations in activity levels are correlated to migratory behaviour in the field and to the reproductive cycle.
\end{abstract}

\section{INTRODUCTION}

In summer, the brackish-water shrimp Palaemon adspersus Rathke lives in shallow water amongst Zostera and brown algae. During autumn it migrates to deeper water where it spends the winter; it returns to shallow water in spring. $P$. adspersus is omnivorous and feeds in the algal zone, but occasionally also swims in open water.

The present study investigates the seasonal and diel activity patterns of Palaemon adspersus. It considers field data, seasonal migrations and the ecology of the species. For a pertinent review on orientation in time of marine animals consult 'Marine Ecology', Volume II: Enright, 1975.

\section{MATERIAL AND METHODS}

Adult Palaemon adspersus were collected by dredging in the algal belts in the non-tidal Aunø Fjord, southern Sealand, Denmark. The salinity in Auno Fjord is $10-15 \%$. After transport to the Helsingør Laboratory, the shrimp were stored in large, shallow basins under the same light and water conditions $(\mathrm{S}=$ 15-20\% under which the experiments were to be done later. The shrimp were adapted to laboratory conditions under natural light conditions for at least 2 weeks prior to experimentation.
Activity was measured in circular aquaria by the photocell technique of Hagerman (1970) and Hørlyck (1973); however, the aquaria were larger (outer diameter: $50 \mathrm{~cm}$, inner diameter: $20 \mathrm{~cm}$, height: $30 \mathrm{~cm}$ ). The passage of the light beam could be varied from close to the bottom to $20 \mathrm{~cm}$ above the bottom. The light beam passed through a Kodak Wratten Filter No. 70, thus allowing only light over $650 \mathrm{~nm}$ - which is invisible to the crustaceans (Waterman, 1960) - to pass through the aquaria. The aquaria were placed under natural light conditions in a room facing east. Activity was normally measured at 1 and $5 \mathrm{~cm}$ over the sandy bottom when recording feeding and swimming. Pieces of net were placed in the aquaria as a substitute for algae. The shrimp were fed 2 to 3 times weekly with Mytilus flesh or mysids.

Light intensities in the experimental aquaria were similar to those in a shallow vegetation-rich Danish fjord, i. e. in the natural biotope of Palaemon adspersus.

Six shrimp were used in each experiment (except for a few with 1 shrimp only), corresponding to a density of 36 shrimp $\mathrm{m}^{-2}$. This density is within the range found in the Aunø Fjord (Fischer, 1978).

Diel activity variations were calculated as percentage deviation of 2 -h values from the corresponding 24-h mean. It was necessary to determine when the shrimp showed behaviour that could be defined as 'active'. This is defined as the level at which the 
number of registrations per 2 -h period exceeds the mean for the corresponding $10-\mathrm{d}$ period. The activity pattern is shown per 10 -d periods. Our experiments were done in the period March 1977 to March 1978.

\section{RESULTS}

Activity of 6 Palaemon adspersus were measured continuously under natural light/dark conditions during the whole experimental period. The resulting normal seasonal and diel activity patterns (Fig. 1) can be used as control for other experiments. Reproducibility was checked by setting up another identical aquarium from April to June. As seen from Figure 1, the pattern was the same in the two aquaria, although the level slightly changed. Thus this experiment could be consi-

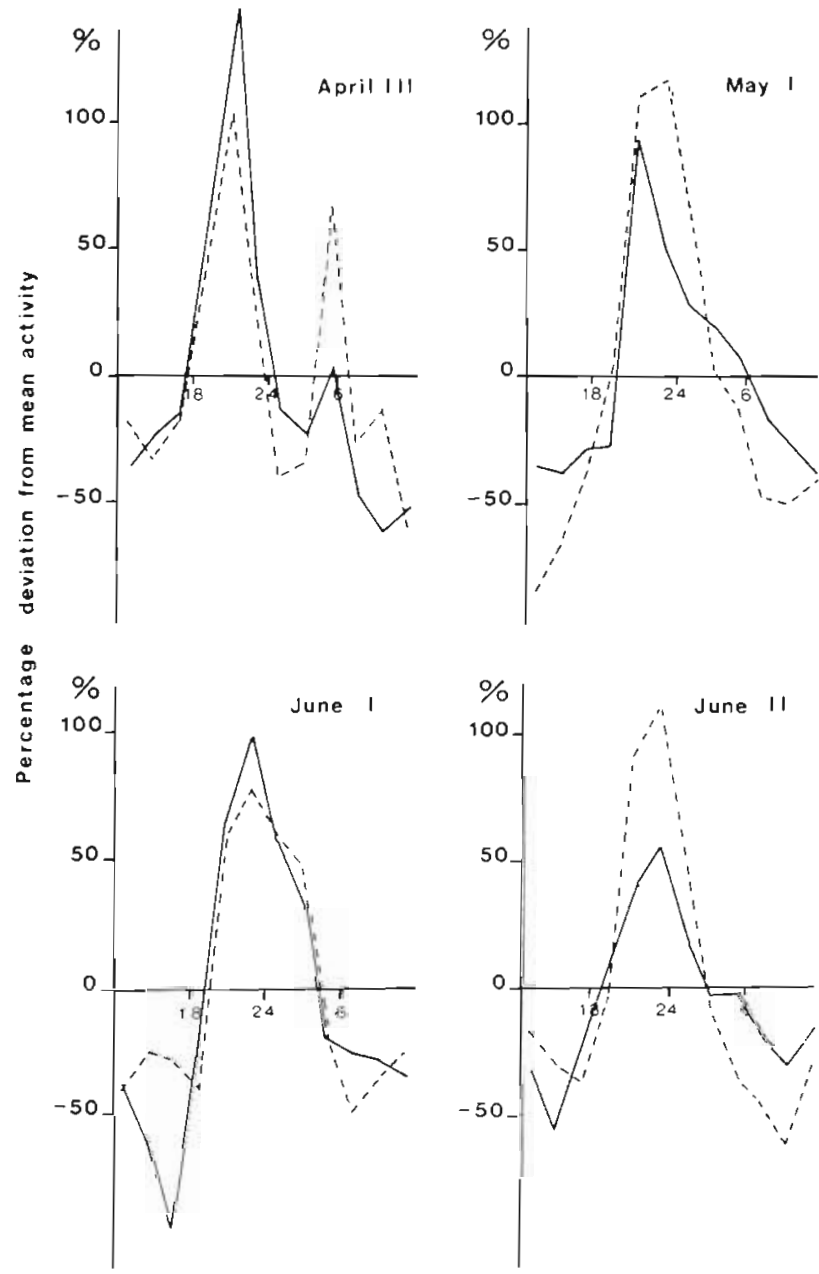

Fig. 1. Palaemon adspersus. Diel activity pattern of six individuals each in two parallel aquaria. Natural light conditions. Each graph gives the average of $10 \mathrm{~d}$ (Decade $\mathrm{I}=1-10 \mathrm{etc}$.) Broken lines: decades from reference aquarium; experiment continued throughout the year. Solid lines: short-time experiment in parallel aquarium; run only during the decades shown. dered to show the normal activity pattern of $P$. adspersus under prevailing conditions.

Seasonal variation, expressed as the mean number of activity recordings per $24-\mathrm{h}$ period per $10-\mathrm{d}$, is shown in Figure 2. Maximum activity was found in summer with 410 recordings $24 \mathrm{~h}^{-1}$, lowest in winter and early

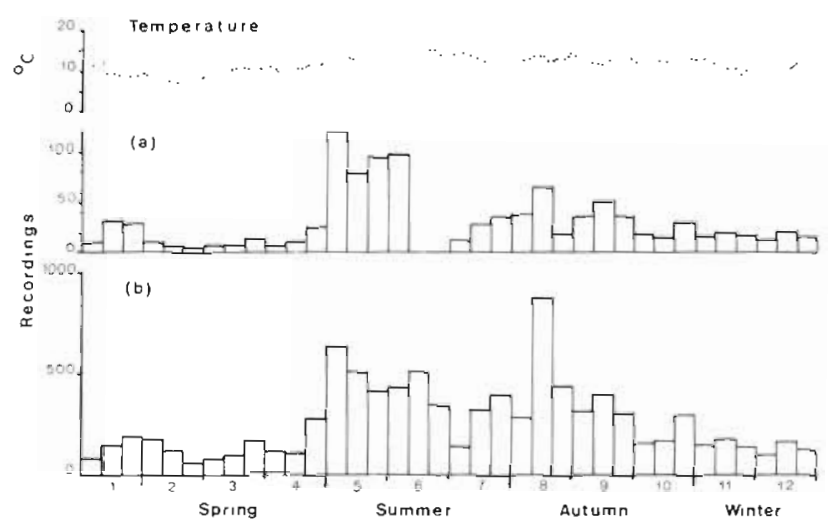

Fig. 2. Palaemon adspersus. Annual variation in activity level. Natural light conditions. (a) Activity, expressed as mean number of recordings $24 \mathrm{~h}^{-1}$ in $10-\mathrm{d}$ periods, recorded $5 \mathrm{~cm}$ above the bottom; (b) as in (a) but recorded $1 \mathrm{~cm}$ above the bottom

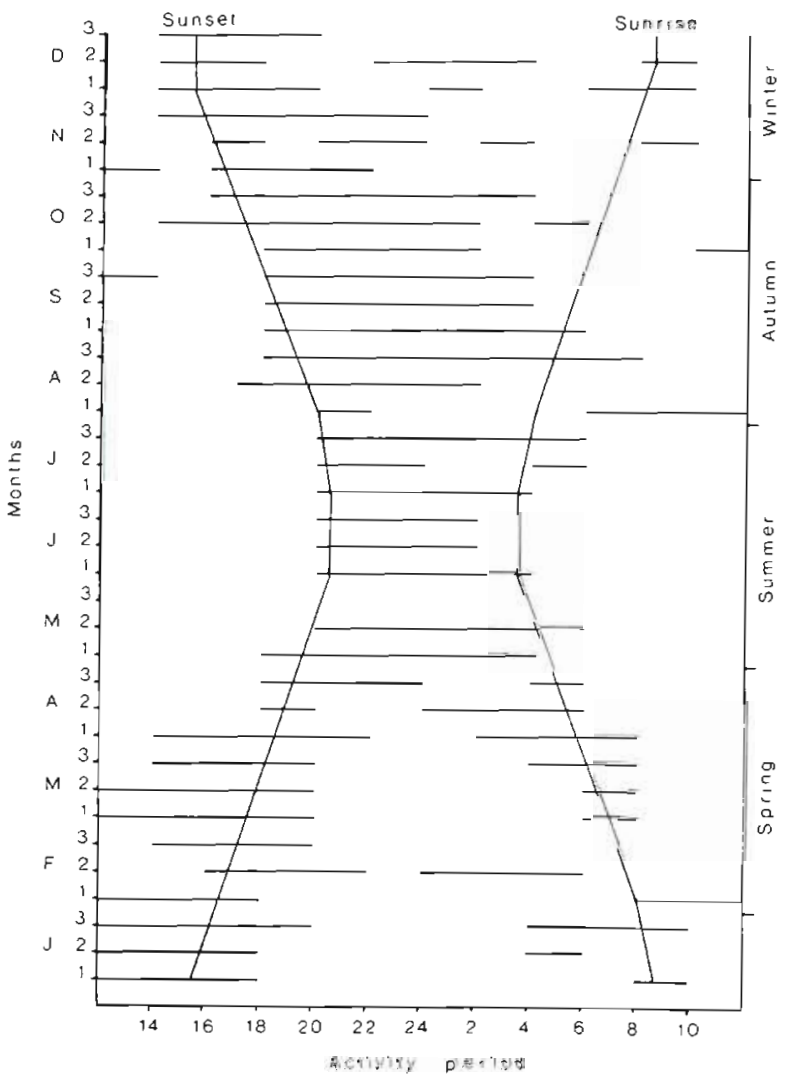

Fig. 3. Palaemon adspersus. Length of active period as a function of season and daylength. Horizontal lines: 2-h periods in which activity exceeded the mean 2 -h activity per 10-d period 
spring (November-April) with 150 recordings. Summer and autumn activities did not differ from each other.

The period with activities exceeding the mean - in relation to season and photoperiod over 10-d intervals - is summarized in Figure 3 ; the actual activity patterns for the same 10-d periods are shown in Figure 4. It is evident that the shrimp are noctumal and that there is a tendency towards a continuous period of activity when the nights are short and towards 2 to 3 periods when the nights are long. In spring the activity is bimodal and there is no difference between activity at sunrise and sunset. The shift from 2 peaks to 1 peak of activity is very pronounced at the end of April. On the contrary, the shift from 1 peak to 2 peaks in late summer is more diffuse. In autumn, maximum activity is reached in the early evening. In winter, there is a great variation in activity level and pattern, related to
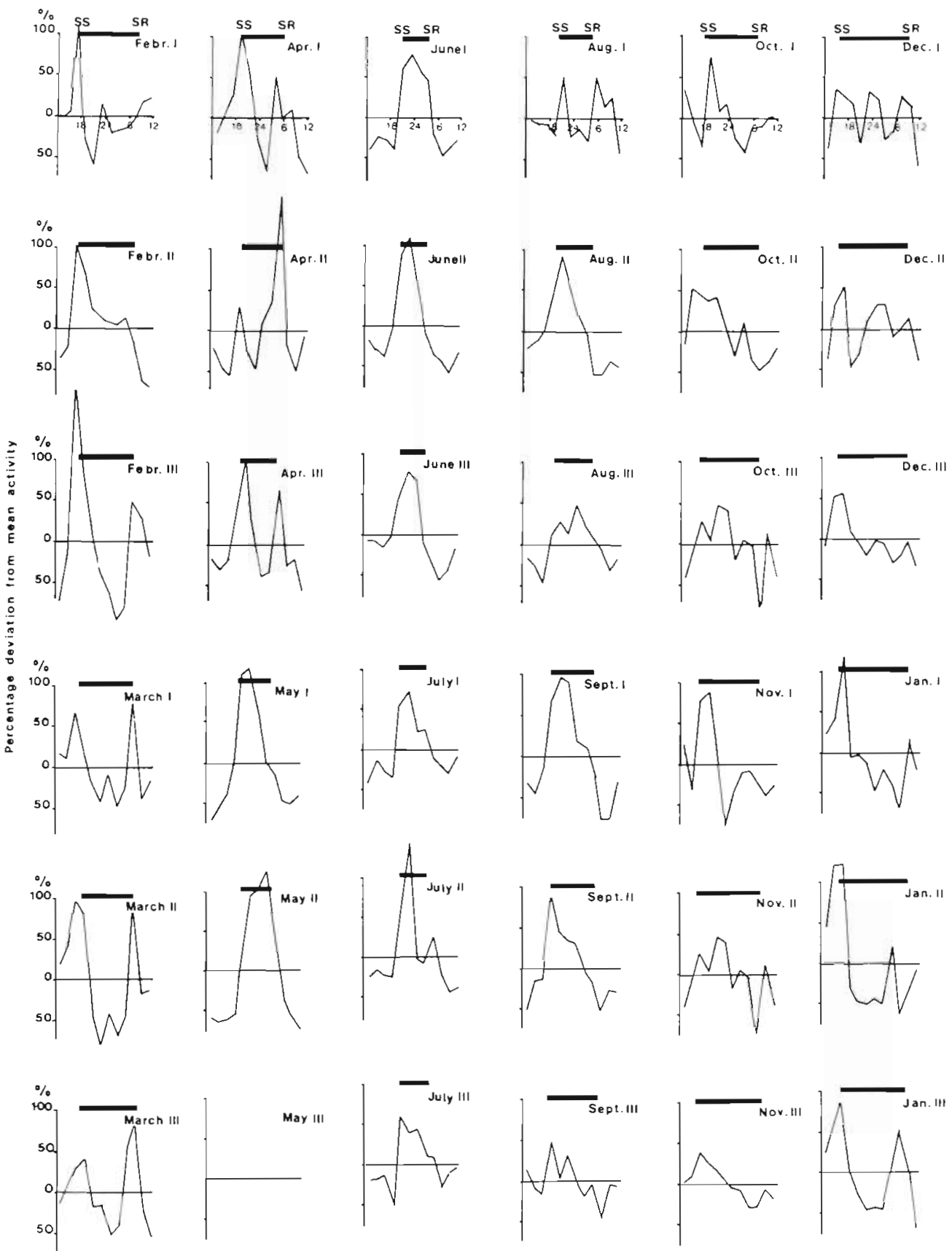

Fig. 4. Palaemon adspersus. Diel activity pattern of six individuals. Natural light conditions. Each graph gives the average of $10 \mathrm{~d}$ (Decade $I=1-10$ etc.). Values expressed as percentage deviation from 24 -h mean. Sunset (SS) and sunrise (SR) indicated 
the very long dark period and the low number of recordings.

The length of the total active period was the same throughout the year: $10 \mathrm{~h}$ per $24 \mathrm{~h}$. The active period starts before sunset; it is closer to darkness the shorter the night. For example, if sunset occurs at 20:30 h, activity started $1.5 \mathrm{~h}$ earlier; if sunset takes place at 15:30 h, activity started $2.75 \mathrm{~h}$ earlier. In summer, when the active period is as long as the dark period, the end of the active period is correlated with sunrise. In autumn, activity ends before sunrise; in spring, after sunrise. In winter, activity generally ceases before the end of darkness, but the variations are large.

A few experiments were conducted to test whether the shrimp influenced each others' activity pattern relative to the activity of solitary individuals. Three aquaria contained one shrimp each (Figs 5 and 6). For females there is good correspondence between the activity patterns of a single individual, summated activity patterns, and the activity in the reference aquarium containing 6 shrimp, both males and females. For males there is a greater variation for individuals, but the summated activity shows the same pattern and level as the reference aquarium.

When activity levels in newly started experiments were recorded there was a very intense activity for the first few days, then a decrease to a stable level after $4-5 \mathrm{~d}$. The activity of the females (Fig. 6) fell to $50 \%$ of that in the reference aquarium; it was difficult to draw a conclusion for the males due to the large individual variation.

To test the influence of food and feeding time on the activity pattern, an experiment was conducted in summer when the shrimp were fed daily at noon with Mytilus flesh for a $10-\mathrm{d}$ period. All remaining food was removed on the 11 th day and no food was given for the following $10 \mathrm{~d}$. The activity pattern and level in this aquarium remained the same as in the reference aquarium. Hence, feeding time did not influence the activity, and neither did 10-d starvation.

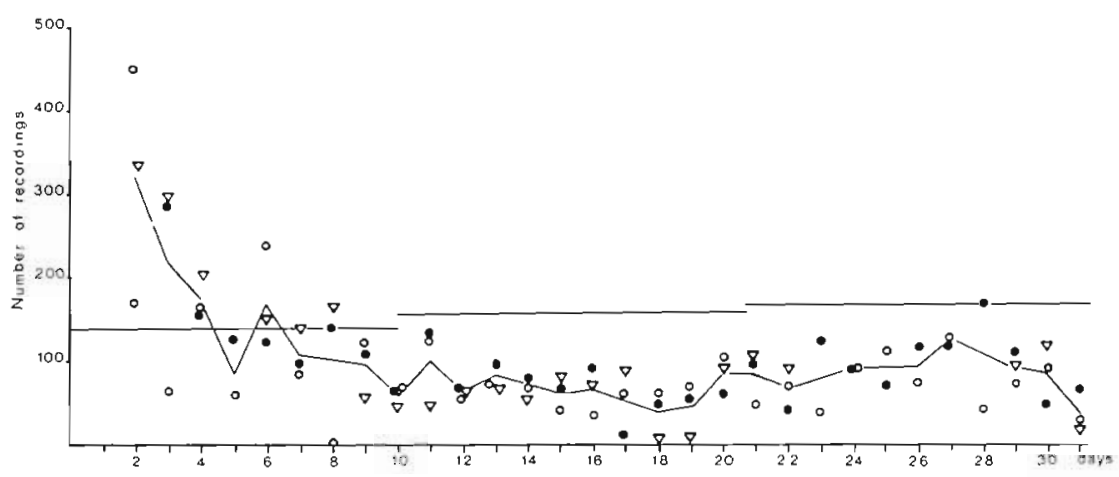

Fig. 5. Palaemon adspersus. Activity levels of individual females. Recordings per 24 -h for 3 shrimp $(\Delta, 0, \bullet)$ in winter 1978 . Mean activity indicated by curve. Values for individual females are multiplied by 6 for comparison with activity levels in the reference aquarium (horizontal lines)

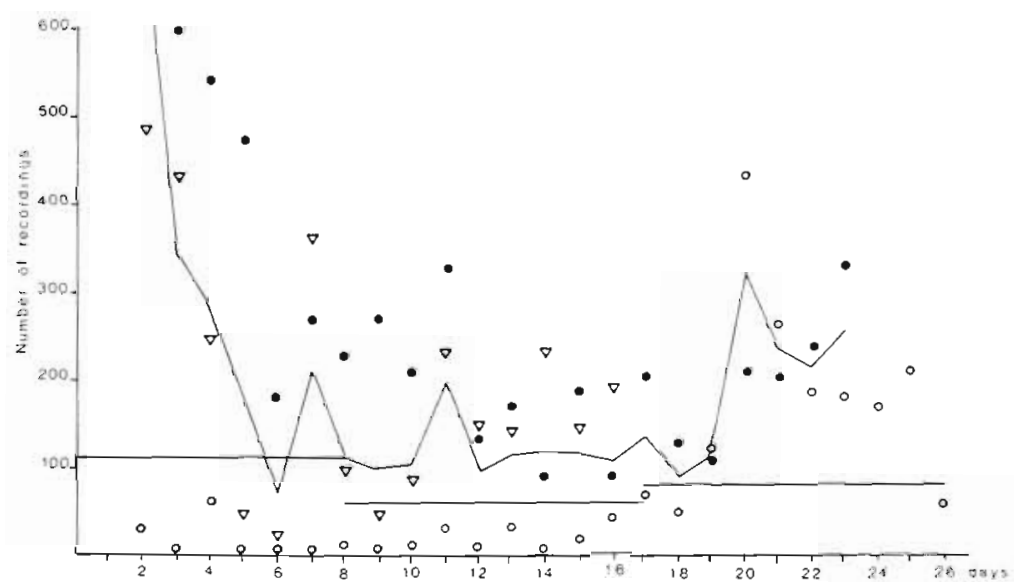

Fig. 6. Palaemon adspersus. Activity levels of individual males. Recordings per 24 -h for 3 shrimp $(\Delta, 0, \bullet)$ in winter 1978 . Mean activity indicated by curve. Values for individual males are multiplied by 6 for comparison with activity level in the reference aquarium (horizontal lines) 


\section{DISCUSSION}

The shrimp were more or less active the whole time, so it was necessary to define a level above which the shrimp could be classified as active. When the number of registrations per $2 \mathrm{~h}$ were more than the mean number per $10 \mathrm{~d}$ the shrimp were defined as active. A similar definition was used by Hagerman (1970) and Quilter and Williams (1971). If another level had been used for defining the active phase, this would only have changed the length of the active period.

The variations in activity level between different 24 $h$ periods might be caused by the laboratory conditions as the number of stimuli must be lower than in the shrimp's natural biotope. Lehmann (1976) noted that the diel rhythm was more pronounced in Uca urvillei and $U$. annulipes when more physical factors were varied. The diel activity patterns in Palaemon adspersus are composed of (a) a number of shortlasting outbursts of activity with short resting periods in between, (b) one or more long activity periods in darkness. The shorter periods occur over the entire 24 -h period; the longer periods are confined to darkness. In nature the shorter activity outbursts will take place in close connection with algal vegetation while the longer nightly activity periods represent feeding and swimming also outside the vegetation. In an area with a sparse Fucus vegetation the nocturnal activity periods represent both seasonal migrations and food search in the open areas. Small activity outbursts during daytime do not exclude feeding during this period. The activity patterm in the laboratory, based on 10 -d periods is similar to what was found in the Aung Ford from catches in creels (Fischer, 1978). The close correlation between field and laboratory results indicate that the definition of the active animal is realistic.

The activity pattern of Palaemon elegans, recorded under constant laboratory conditions, broke down faster in groups of 20 shrimp than in single individuals (Rodriques and Naylor, 1972), a result that might be due to overcrowding in the aquarium (400 shrimp $\mathrm{m}^{-2}$ ). In Talitrus saltator (Bregazzi and Naylor, 1972) the activity is more regular in recordings of groups than in single animals, it is supposed that the start of activity is synchronized to the first active individuals. At increased densities the intensity of activity in Talitrus decreased. The same was noted for Uca pugilator by Atkinson and Naylor (1973) and stated to be due to social interactions. In contrast to this a fall in intensity was noted for Palaemon adspersus in the present investigation, when the number of individuals decreased. Whether this was caused by less disturbances from other shrimp or a real social behaviour in the group can not be determined.

The feeding technique used here was also employed by Hagerman (1970) with no influence on the activity pattern of Crangon vulgaris; however, starving C. vulgaris increased the activity level. Feeding of starved Penaeus semisulcatus and $P$. monodon had some effect (Moller and Jones, 1975), but daily food supplied outside the active period did not influence the activity pattern. Fuss and Ogren (1966) also found that several days of starvation, followed by feeding, did not change the light/dark-determined activity pattern of $P$. duorarum.

\section{Seasonal Rhythms}

Periods with a high activity level, i. e. summer and autumn, correspond with Palaemon adspersus living in shallow water (Fischer, 1978). The increased activity level is not exclusively confined to the active period, but can be seen also during the inactive period. The start in the laboratory for the period with a high activity level (first decade of May) corresponds to the shrimp migration from deeper winter quarters to shallow summer areas. The laboratory-started increase in activity can thus be related to a migratory phase combined with a general increase in activity caused by gonad development.

In the field the migratory phase is parallelled by a rapidly increasing water temperature. A temperature change did not occur in the laboratory so the start of the high activity period might be caused by a certain day/night length, a certain stage of gonad development, but most probably a combination of both. The gonad development for the laboratory shrimp was similar to the fjord population in early spring.

A seasonal difference in activity was also found in Panulirus with 1 short or 1 long phase (Kanciruk and Hernkind, 1973) $24 \mathrm{~h}^{-1}$. The long period occured during reproduction and it was supposed that the change was synchronized by a certain photoperiod. In Palaemonetes pugio the gonad development was shown to be governed by the photoperiod. (Little, 1968).

The end of the active period in October was more diffuse corresponding with field data where the end of reproduction and the autumn migration were sex and age dependent and extended over a longer period (Fischer, 1978).

\section{Diel Rhythms}

Diel activity pattern showed a uni-, bi- or trimodal curve depending on the length of the dark period. This general picture was also shown for Crangon vulgaris (Hagerman, 1970). The start of the active phase was 
earlier at longer periods of darkness and one might assume that this was dependent not only on the change from light to dark, but connected to a certain light intensity. In summer this light intensity will be reached at a later time than in winter.

A close connection between the onset of activity and change from light to dark has been shown for a large number of nocturnal animals. A direct connection between activity and a certain light intensity was found by Chapman and Johnson (1975) and Naylor and Atkinson (1976) for Nephrops norvegicus. The onset of activity in Penaeus duorarum was correlated to the beginning of darkness, the end of the active phase was not so strictly correlated to the end of the night (Fuss and Ogren, 1966). This was the case also for Palaemon adspersus.

The length of the active period and the subdivision in smaller periods is probably regulated by an endogen mechanism. The endogenous component for Paranephrops and Carcinus has been found to depend on the season, with almost no control in winter (Atkinson and Parsons, 1973; Quilter and Williams, 1977). The diel rhythm of Palaemon adspersus in winter showed no clear rhythmicity. In nature the low water temperature will decrease activity and the value of a defined period at this season will be minimal. Honegger (1973) suggests that an endogenous circannual cycle synchronized by light/dark conditions and connected to the reproductive cycle is responsible for the seasonal variation in activity rhythms in $U$ ca crenulata. A similar reasoning might be applied to Palaemon adspersus.

In certain areas a synchronized diel rhythm might help to keep the population together, especially in connection with migrations. Palaemon is omnivorous (Inyang, 1976) and synchronizing with the rhythm of a prey is not probable. Among environmental factors, oxygen content is the only one with which the diel rhythm of Palaemon might be correlated. P. adspersus is sensitive to oxygen lack (Hagerman and Weber, in prep.) and Palaemon will leave areas with a pronounced nightly oxygen decrease. However, the oxygen pulse in shallow waters occurs only and sporadically in summer and as the diel rhythm of Palaemon is evident in all seasons an oxygen pulse can not be responsible but might under certain circumstances increase the activity level.

Predators on Palaemon are plaice, flounders and young cod (De Groot, 1971); these fishes are visual predators and feed mainly in daytime and at sunrise and sunset. If the annual variation in activity patterns of these fishes are compared with that of Palaemon it is evident that they are mirror pictures of each other with only minimal overlap. Thus, considering its predators, a concentration of the swimming activity of $P$. adspersus to periods of darkness will be an advantage.
Acknowledgements. Dr. Donald McLusky, University of Stirling, kindly critized the manuscript.

\section{LITERATURE CITED}

Atkinson, R. J. A., Naylor, E. (1973). Activity rhythms in some burrowing decapods. Helgoländer wiss. Meeresunters. 24: 192-301

Atkinson, R. J. A., Parsons, A. J. (1973). Seasonal patterns of migration and locomotor rhythmicity in populations of Carcinus. Netherl. J. Sea Res. 7: 81-93

Bregazzi, P. K. (1972). The effect of low temperature upon the locomotor activity rhythm of Talitrus saltator (Montagu) (Crustacea, Amphipoda). J. Exp. Biol. 57: 393-399

Bregazzi, P. K., Naylor, E. (1972). The locomotor activity rhythm of Talitrus saltator (Montagu) (Crustacea, Amphipoda). J. Exp. Biol. 57: 375-391

Chapman, C. J., Johnstone, A. D. F. (1975). The behaviour and ecology of the Norway lobster, Nephrops norvegicus L. In: Barnes, H. (ed.) Proceedings of the 9th European Marine Biology Symposium. Aberdeen University Press, Aberdeen, pp. 59-74

Enright, J. T. (1975). Orientation in time: endogenous clocks. In: Kinne, O. (ed.) Marine ecology, Vol. II, Physiological mechanism, Part 2. Wiley, London, pp. 917-944

Fischer, K., 1978. Migrationer og populationsdynamik hos Palaemon adspersus Rathke. M. Sc. thesis, University of Copenhagen, Copenhagen

Fuss, C. M., Ogren, L. H. (1966). Factors affecting activity and burrowing habits of the pink shrimp, Penaeus duorarum Burkenroad. Biol. Bull. mar. Biol. Lab., Woods Hole 130: 170-191

Groot, S. J. De (1971). On the interrelationships between morphology of the alimentary tract, food and feeding behaviour in flat-fish (Pisces, Pleuronectiformes). Netherl. J. Sea Res. 5: 121-196

Hagerman, L. (1970). Locomotory activity pattems of Crangon vulgaris. Ophelia 8: 255-266

Hagerman, L., Weber, R. (in prep.). The respiratory role of the blood in Palaemon adspersus Rathke

Honegger, H.-W. (1973). Rhythmic motor activity responses of the California fiddler crab (Uca crenulata) to artificial light conditions. Mar. Biol. 18: 19-31

Horlyck, V. (1973). Seasonal and diel variation in the rhythmicity of Idotea baltica (Pallas) and I. granulosa (Rathke). Ophelia 12: 117-127.

Inyang, N. M. (1976). A study of the Baltic shrimp, Palaemon adspersus var. fabricii (Rathke), in Kiel Bay. Ph. D. thesis, University of Kiel, Kiel

Kanciruk, P, Herrnkind, W. F. (1973). Preliminary investigations of the daily and seasonal locomotor activity rhythms of the spiny lobster, Panulirus argus. Mar. Behav. \& Physiol. 1: 351-359

Lehman, U. (1976). Interpretation of entrained and free-running locomotor activity patterns of Uca. In: De Coursey, P. P. J. (ed.) Biological rhythms in the marine environment. University South Carolina Press, Colombia, pp. 77-91

Lehman, U., Neumann, D., Kaiser, H. (1974). Gezeitenrhythmus und spontane Aktivitätsmuster von Winkerkrabben. J. comp. Physiol. 91: 187-221

Little, G. (1968). Induced winter breeding and larval development in the shrimp palaemonetes pugio Holthuis (Caridae, Palaemonidae). Crustaceana 2 (Suppl.); 19-26

Moller, T. H., Jones, D. J. (1975). Locomotory rhythms and burrowing habits of Penaeus semisulcatus (de Haan) and P. monodon (Fabricius) (Crustacea: Penaeidae). J. exp. mar. Biol. Ecol. 18: 61-77 
Naylor, E. (1960). Locomotory rhythms in Carcinus maenas (L.) from non-tidal conditions. J. exp. Biol. 37: 481-488

Naylor, E., Atkinson, R. J. A. (1976). Rhytmic behaviour of Nephrops and some other marine crustaceans. Persp. Exp. Biol. (Zool.) 1: 135-143
Quilter, G. G., Williams, B. G. (1977). Circadian activity Ihythms in the crayfish Paranephrops zealandicus (Crustacea). J. Zool. Lond. 182: 559-571.

Rodriquez, G., Naylor, E. (1972). Behavioural rhythms in littoral prawns. J. mar. biol. Ass. U. K. 52: 81-95

This paper was submitted to the editor; it was accepted for printing on February 21, 1980. 